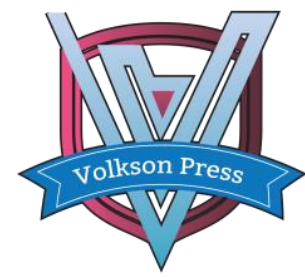

Contents List available at VOLKSON PRESS

Economics \& Management Innovations(EMI)

DOI : http://doi.org/10.26480/icemi.01.2017.128.130

\title{
REVIEW OF SOCIAL PROTECTION TO ALLEVIATE POVERTY IN THAILAND
}

\author{
Saneh Dechawongse $^{1_{*}}$, Somporn Gomaratut ${ }^{2}$, Siriporn Sajjanand ${ }^{3}$

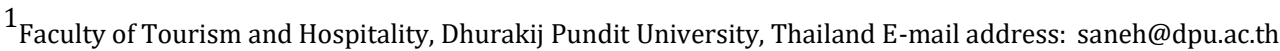 \\ 2 Faculty of Arts, Dhurakij Pundit University, Thailand E-mail address: somporng@dpu.ac.th \\ ${ }^{3}$ Institute for Social and Economic Sciences, Dhurakij Pundit University, Thailand \\ E-mail address: ecasssir@yahoo.com
}

This is an open access article distributed under the Creative Commons Attribution License, which permits unrestricted use, distribution, and reproduction in any medium, provided the original work is properly cited.

\section{ARTICLE DETAILS}

\section{Article History:}

Received 02 october 2017

Accepted 06 october 2017

Available online 11 october 2017

\section{Keywords:}

Social protection, Sustainable development, Poverty in Thailand.

\section{ABSTRACT}

The objectives of this work were to study the current situation of social protection in Thailand and to analyze the gaps in achieving the sustainable development in Goal 1, Target 1.3. The results of the study found that the social protection in Thailand consisted of social security, health insurance, labour protection, social welfare and other social services. In 2015, 20.50\% of the total populations obtained the social protection by Social Security Act B.E. 2533 (1990) under Article 33, 39 and 40. About 7,671 million baht was allocated annually for social protection and social welfare services by the basic rights of Thai people, especially the poor and the vulnerable. The gaps in achieving the goal of sustainable development in Goal 1, Target 1.3 were; inconsistent state policy and unsystematic measures and projects. The social protection was mostly allocated in the form of money, allowance, grant, fund and free welfare. The appropriate measures other than money from taxation should be implemented and the social protection system should be unique, relevant and sustainable in finance.

\section{Introduction}

Social protection is a set of public and private policies and programmes aimed at preventing, reducing and eliminating economic and social vulnerabilities to poverty and deprivation. And it also protects people from the risks in a chance of development in order to use their potential such as children, the older, pregnant, disables, the sick (UNICEF, 2013)

From the year 2000 onwards, Thailand has gradually developed its social protection system for people in all ages and it has been improving accordingly by the vision of the Tenth National Economic and Social Development Plan (2007-2011) and the Eleventh Plan (2012-2016). In the past ten-year round, social protection system in Thailand has been developed in many ways, such as health insurance, 15-year free education, standard of living with the 300 baht minimum wage a day and the monthly living allowance for the elder.

From 2017 to 2030 or the next 15 years, the UN aims to develop countries in the world under sustainable development with 17 aims. The first aim is No Poverty consisting of 7 targets and 12 indicators. Social protection is one among the 7 targets.

As a member of the UN, the government of Thailand has to kick off the nation development under the framework designated by the UN. The government led by General Prayut Chan-ocha assigned the state agencies to move the development under the goals set by the UN. The Interior Ministry is the main agency responsible for Goal 1: End Poverty in All its Forms Everywhere. The meeting of working group of the Ministry of Interior on December 16, 2016 categorized and set the significant order of the 17 targets in Sustainable Development Goal. Target 1:3 Social Protection was approved as the most significant and urgent issue to be implemented within 5 years.

The Thailand Research Fund (TRF), a state agency under the Prime Minister Office, has a burden in supporting and encouraging the knowledge in local and national levels through research based movement in order to solve problems and arrange research fund for finding the body of knowledge in Sustainable Development Growth with 17 goals. The team of researchers is interested in the study of the current situation of social protection in Thailand, research gap and policy gap in moving the social protection in Thailand to achieve the goal in Sustainable Development Growth as the government expects.

\section{Objectives of the study}

The study covers 2 objectives: To study the current situation of social protection in Thailand, and To study and analyze the gap(s) for achieving the Sustainable Development Growth in Target 1.3 of Goal 1

\section{Methodology}

The study procedures began with collecting and analyzing the data concerning social protection in Thailand obtained from sources, and then participating in meetings and group discussions with state agencies, private agencies, and civil society on Goal 1.

\section{The Conceptual Framework}

The study is limited under the conceptual frame of Sustainable Development Growth, Goal 1: End Poverty in All its Forms Everywhere Target 1.3 Implement nationally appropriate social protection systems and measures for all, including floors, and by 2030 achieve substantial coverage of the poor and the vulnerable, and indicator 1.3.1 Proportion of population covered by social protection floors/systems, by sex, and distinguishing children, unemployed persons, older persons, persons with disabilities, pregnant women, newborns, work injury victims, and the poor and the vulnerable.

\section{Results of the study}

\subsection{The current situation of social protection in Thailand}

5.1.1 In overview, the social protection in Thailand consists of insurances which are classified into social and health insurance, labour protection, public welfare and other social services.

5.1.2 The data from Research and Development Department, Office of Social Insurance 2015, indicated that in $201513,789,190$ people or $20.50 \%$ of 67.2 million populations have accessed the social protection according to the Social Protection Act, article 33, 39 and 40. In that 
number, 6.57 million people are male and 7.21 are female.

5.1.3 7,671 million baht was allocated to strengthen social security and improve the quality of life of people, especially the vulnerable.

5.1.4 The target populations to access social protection system and social protection measure consist of:

Children: According to National Statistical Office (2015), there were $21,813,333$ children and youths or $33.19 \%$ of the total populations. Social securities provided to children are as follows: 30 child-care centers throughout the country, improving life quality of the newborns through nurseries and giving support to private nurseries in 76 provinces, the measures to prevent and reduce the risks of human trade by child-labour protection, 3-year 600 baht bounty per month for the newborns in the poor family and family at risk of poverty, the subsidies for registered employees' newborns according to the Social Insurance Act, article 33 and 39, and 15-year free education Employed persons: The survey in 2016 revealed that there were 38.38 million employed workers in the country; 17.0 million was registered workers and 21.3 million was non-registered workers. The social protection allocated by the state to both registered and non-registered workers were as follows: social insurance system, compensation and labour welfare fund, National Savings Fund (NSF), health care rights in social insurance, and basic health rights under Basic Health Insurance Act 2002 Unemployed persons: According to the data from National Statistical Office, March 2017, there were 496,000 unemployed persons, $23.75 \%$ increased from 2016. In that amount, the rate of employed men was higher than of women. Of 129,558 unemployed workers applying for compensation from social security fund, those who graduated in higher education were at the highest rate.

The elderly: From the data of National Statistical Office 2016, there were 10.91 million elderly at the age more than 60 years. 4.02 million older people were employed and 6.86 million were unemployed. For the social protection, the elderly from public sector received pension and civil servant medical benefit scheme, private sectors' employees received lump sum pension from the Provident Fund and monthly allowance from social insurance. The rest of the elderly received elderly subsistence allowance 600-1,000 baht a month. National Plan for the Elderly 20022021 was set up by the government and Strategic Plan for the Elderly, Phase 1 (2016-2021) and 1,065 million baht was allocated for the qualified elderly society.

The disable: The National Statistical Office 2016 revealed that there were $1,737,469$ registered disables or $2.64 \%$ of the whole populations. The social protection that was provided to the disables by the labour law in article 33, 34 and 35 to recruit the disables in government and private sectors resulting to 31,355 disables to be employed and 8,672 disables to run their own work. There are funds to support and improve life quality of the disables, such as Occupation Loan Fund, disabled persons support contributions 800 baht per head per month and other facilities for the disables in 50 provinces nationwide.

Work injury employees: There are employees injured from their work every year. The government established 2 funds for this purpose; Compensation and Safety Fund and Health and Environment Fund. The poor and vulnerable: According to the Protection for the Deprived Act 2014, the state has to provide the deprived with welfare, land, home, loan, occupation training, occupation development training, registration for the poor, and allocate annual budget for them.

5.2 The gaps to achieve the target 1.3 and indicator 1.3 .1 of the UN

Table 1 current situation and the target

\begin{tabular}{|c|c|c|}
\hline $\begin{array}{l}\text { Target and } \\
\text { Indicator }\end{array}$ & The current situation of social protection in Thailand & $\begin{array}{l}\text { The gaps between the current } \\
\text { situation and the target }\end{array}$ \\
\hline \multirow[t]{2}{*}{$\begin{array}{l}\text { Target 1.3 } \\
\text { Implement } \\
\text { nationally } \\
\text { appropriate social } \\
\text { protection systems } \\
\text { and measures for all, } \\
\text { including floors, and } \\
\text { by } 2030 \text { achieve } \\
\text { substantial coverage } \\
\text { of the poor and the }\end{array}$} & $\begin{array}{l}\text { Children } \\
\text { 1. Education fund for state servants' children } \\
\text { 2. } 600 \text { baht allowance a month under social security fund } \\
\text { for children aged } 0-3 \text { years of the insured parents } \\
\text { 3. } 0-3 \text { years children of the poor family or poverty risk } \\
\text { family receive } 600 \text { baht allowance a month } \\
\text { 4. } 15 \text {-year free education for every child }\end{array}$ & $\begin{array}{l}\text { The allowance for children in the } \\
\text { poor family and poverty risk } \\
\text { family should be extended from } 3 \\
\text { years to } 1 \text { years. }\end{array}$ \\
\hline & $\begin{array}{l}\text { Emplovees } \\
\text { Illness } \\
\text { 1. The medical care for state servants from the Comptroller } \\
\text { General's Department of Ministry of Finance. }\end{array}$ & No gap found \\
\hline
\end{tabular}

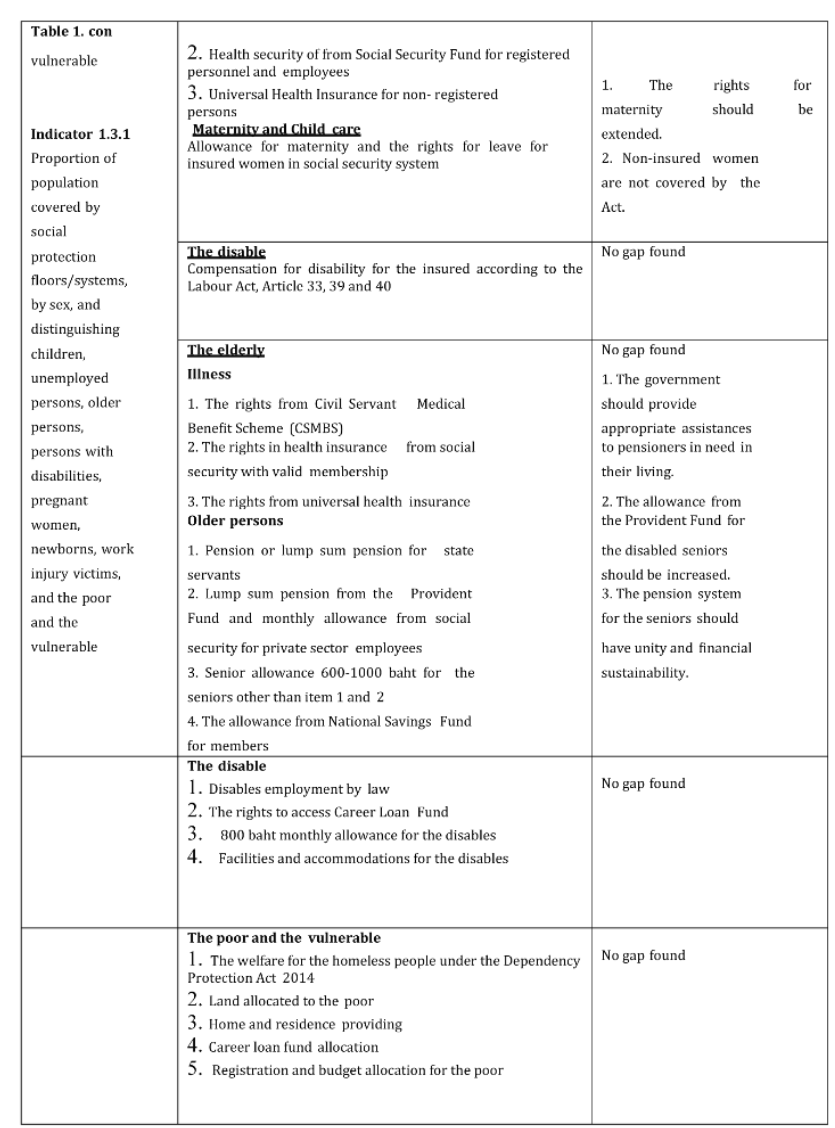

Conclusion: In 2001, the universal coverage scheme policy (UCS) was implemented in Thailand. It was the start of social protection for people in all ages and was successful by the aim of National Economic and Social Development Plan 11. The social protection has been implemented according to 20-year National Strategy (2017-2037) with the aim that "People have life security, work, and secure and sufficient income in living a life, rights protection and welfare for the better life quality."

Although the social protection in Thailand has been settled and developed in some levels, but it is not in a systematic process, has policy gap and problems in implementation. It should be studied and the social protection competency should be compared with those of the other countries to find out the good practices and set for the social protection roadmap in short, middle and long terms to protect people in every form and everywhere in Thailand.

\section{References}

1. Bureau of the Budget. (2016). Analytical Study of the Budget Act Draft for Fiscal Year 2016. Bangkok: The parliament Office.

2. Bureau of the Budget. (2017). Budget for Fiscal Year 2014-2017. Bangkok: Office of the Prime Minister.

3. Division of Strategy and Plan. (2016). 2-Year Operating Results Report. Bangkok: Ministry of Social Development and Human Security.

4. Division of Strategy and Plan. (2016). Action Plan of Ministry of Social Development and Human Security in Fiscal Year 2016. Bangkok: Ministry of Social Development and Human Security.

5. International Labour Organization (ILO) and Joint Committee of the United Nations in Thailand. (2013). Evaluation of Social Protection from the Nation Consultation to step in the Context of Thailand. Bangkok: Office of International Labour in Asia and Pacific Region.

6. National Statistical Office. (2015). National Health and Welfare Survey B.E. 2558 (2015). Bangkok: Ministry of Digital Economy and Society.

7. National Statistical Office. (2017). Report of People's Employment Survey in February 2017. Bangkok: Ministry of Digital Economy and Society.

8. Office of the National Economics and Social Development Board. (2017). The Twelfth National Economic and Social Development Plan. Bangkok: Office of the Prime Minister. 
9. Office of the National Economics and Social Development Board. (2017). Report of Poverty and Disparity Analysis in Thailand. Bangkok: Office of Database and Social Indicators.
10. Paramethee Wimonsiri. (2016) National 20-year Strategy: Future Thailand to Stability, Prosperity and Sustainability. Bangkok: Office of the Promotion and Commission Insurance Business. 